\title{
VAMOS VER QUEM É QUE ACABA, O RESTO DA EMPELEITADA: ARTE INDÍGENA ENTRE OS POTIGUARAS DA ALDEIA CATU DOS ElEOTÉRIOS E SAGI- TRABANDA
}

\author{
FLÁVIO RODRIGO FREIRE FERREIRA ${ }^{1}$ \\ NILTON XAVIER BEZERRA ${ }^{2}$
}

\begin{abstract}
RESUMO
Desde o final da década de 1990 com abertura política e uma Constituição da República garantidora de direitos coletivos, os grupos indígenas da etnia Potiguara localizados no estado do Rio Grande do Norte, a partir do contexto de emergências-étnicas, têm afirmado publicamente sua identidade. 0 povo Potiguara pertence linguisticamente ao tronco tupi e há séculos habitam o litoral dos estados da Paraíba e do Rio Grande do Norte. Os territórios coletivos dos Potiguaras do litoral sul do RN estão compreendidos nas aldeias Catu dos Eleotérios e Sagi-Trabanda, a primeira localizada entre os municípios de Canguaretama e Goianinha, às margens do rio Catu; a segunda situa-se no município de Baía Formosa na divisa com o estado da Paraíba. Esses grupos vivem processos de resistência e enfrentamentos, buscando visibilidade e o fortalecimento de suas identidades. Nesse contexto de resistência, 0 artesanato indígena aparece como uma forma representativa de sua cultura material e adquire fundamental importância para as duas comunidades. Diante desse cenário, a pesquisa etnográfica, buscou - a partir da valorização dos patrimônios étnicos dos grupos e reconhecendo a cultura como forma de resistência desses povos - contribuir com o processo de fortalecimentos de suas identidades, elegendo a produção artesanal/artística indígena como representação social a ser investigada.
\end{abstract}

\section{PaLAVRas-ChaVE \\ Arte; Povos Indígenas; Potiguaras; Catu dos Eleotérios; Sagi-Trabanda \\ LET'S SEE WHAT IT IS FINISHED, THE REST OF THE HARVESTED: INDIGENOUS ART BETWEEN THE POTIGUARAS OF CATU OF ELEOTÉRIOSAND SAGI-TRABANDA}

\begin{abstract}
Since the late 1990s, indigenous groups of the Potiguara ethnic group located in the state of Rio Grande do Norte have publicly affirmed their identity. The Potiguara people belong linguistically to the trunk Tupi and for centuries they inhabit the coast of the states of Paraíba and Rio Grande do Norte. As territories of the Potiguaras of the RN are comprised the Catu Eleoterios and Sagi-Trabanda villages, the first is located in the municipalities of Canguaretama and Goianinha, on the banks of the Catu river; The second is in the municipality of Baía Formosa on the border with the state of Paraíba. Both live in processes of resistance and confrontation, seeking visibility and the strengthening of their identities. In this context of resistance, the indigenous craftsmanship appears as a representative form of their cultures and acquires fundamental importance for the two communities. In view of this scenario, ethnographic research sought - from the valorization of the ethnic
\end{abstract}

\footnotetext{
1 Doutor em Ciências Sociais pela UNICAMP e Mestre em Antropologia Social pela UFRN. Desde o ano de 2012 é professor do IFRN onde coordena o Observatório da Diversidade. É pesquisador do grupo Cultura, Identidade e Representações Simbólicas (Cirs/UFRN). Contato: flaviorodrigoff@yahoo.com.br.

${ }^{2}$ Mestre e Especialista em Antropologia Social, graduado em Artes Plásticas pela UFRN. Desde o ano de 2010 é professor do IFRN onde coordena o Núcleo de Estudos Afro Brasileiros e Indígenas do IFRN Campus Canguaretama. Contato: nilton.xavier@ifrn.edu.br; niltonxavierb@gmail.com.
} 
heritage of the groups and recognizing the culture as a form of resistance of these peoples - to contribute with the process of strengthening their identities, choosing the indigenous artisan / artistic production as a cultural representation to Be investigated.

KEYWORDS

Art; Indian people; Potiguaras; Catu dos Eleotérios; Sagi-Trabanda

\title{
VOYONS QUI VA ACHEVER LE RESTE DU TRAVAIL: ART INDIGĖNE CHEZ LES POTIGUARAS DES VILLAGES DE CATU DOS ELEOTÉREOS ET SAGI-TRABANDA
}

\begin{abstract}
RÉSUMÉ
Depuis la fin des années 90, dans le contexte d'ouverture politique et de la naissance d'une Constitution républicaine qui assurait les droits collectifs, les groupes indigènes de l'ethnie Potiguara, établis dans l'état du Rio Grande do Norte (Brésil), ont publiquement affirmé leur identité. Ils appartiennent linguistiquement au tronc Tupiet pendant des siècles habitent la côte des états de la Paraíba et du Rio Grande do Norte. Les territoires collectifs de la côte sud du de ce dernier état se localisent dans les villages indigènes Catu Eleotérios (entre les villes de Canguaretama et Goianinha, sur le bord de la rivière Catu) et Sagi-Trabanda (dans la ville de Baía Formosa, proche à la frontière avec l'état de la Paraíba). En vivent des processus de confrontation politique, ces groupes cherchent rendre plus visibles et plus solides leurs identités. Dans ce contexte de résistance, l'artisanat autochtone apparaît comme une forme représentative de leur culture matérielle et acquiert une importance fondamentale pour les deux communautés. Au regard de ce scénario, à partir de la valorisation de leur patrimoine ethnique et reconnaissant la culture comme une forme de lutte, la recherche ethnographique a eu pour but contribuer dans ce processus de renforcement identitaire, en choisissant la production artisanale / artistique comme représentation sociale à étudier.
\end{abstract}

MOTS-CLÉS

Art ; peuples indigènes; Potiguaras ; Catu dos Eleotérios ; Sagi-Trabanda.

\section{VAMOS VER QUIEN ES QUE ACABA, EL RESTO DE LA EMPELECITA:ARTE INDÍGENA ENTRE LOS POTIGUARAS DE LA ALDEA CATU DE LOS ELEUTERIOS Y SAGI-TRABANDA}

\begin{abstract}
RESUMEN
Desde el final de la década de 1990 con la apertura política y una Constitución de la República que garantiza a los derechos colectivos, los grupos indígenas de la etnia Potiguara localizados en el departamento de Rio Grande do Norte, a partir del contexto de emergencias-étnicas, vienen afirmando públicamente su identidad. El pueblo Potiguara pertenece lingüísticamente a la familia tupi y hace siglos habitan el litoral de los departamentos de Paraíba y de Rio Grande do Norte. Los territorios colectivos de los Potiguaras del litoral sur de RN están ubicados en las aldeas Catu dos Eleotérios y Sagi-Trabanda, la primera localizada entre los municipios de Canguaretama y Goianinha, a las márgenes del rio Catu; la segunda se sitúa en el municipio de Baía Formosa en la divisa con el departamento de Paraíba. Esos grupos viven procesos de resistencia y enfrentamientos, buscando visibilidad y el fortalecimiento de sus identidades. En ese contexto de resistencia, la artesanía indígena aparece como una forma representativa de su cultura material y adquiere fundamental importancia en ambas comunidades. Frente a ese escenario, la pesquisa etnográfica, buscó - a partir de la valorización de los patrimonios étnicos de los grupos y reconociendo a la cultura como forma de resistencia de dichos pueblos - contribuir con el proceso de fortalecimientos de sus identidades, eligiendo la producción artesanal/artística indígena como representación social a ser investigada.
\end{abstract}

Palabras ClaVe

Arte; Pueblos Indígenas; Potiguaras; Catu dos Eleotérios; Sagi-Trabanda. 


\section{INTRODUÇÃO}

No contexto dos estudos em etnologia indígena brasileira, a arte é expressão simbólica e material da cultura das mais relevantes, pois envolve simultaneamente aspectos materiais e imateriais, reveladora de conhecimentos específicos constituídos nas relações que os sujeitos estabelecem entre si, com o meio natural e com outros grupos sociais. Nesse sentido, buscaremos demonstrar que a feitura de processos artesanais dos povos indígenas, possuem um tempo diferenciado compreendido a partir do contexto sociocultural especifico da etnia Potiguara (VIEIRA, 2010). Concordamos com Lagrou (2010) quando defende a "inexistência, entre os povos indígenas, de uma distinção entre artefato e arte, ou seja, entre objetos produzidos para serem usados e outros para serem somente contemplados" (p. 03). Iremos considerar também o horizonte da produção material dos índios do nordeste e o seu complexo contexto histórico e seus processos sociais (OLIVEIRA, 1999a).

A arte entre os povos indígenas revela um importante aspecto dos seus esquemas conceituais, práticas cotidianas, processos sociais e/ou simbólicos. Assim, evitaremos "tomar como referência nenhuma definição de arte previamente dada, seja ela estética, interpretativa ou institucional" (LAGROU, 2010, p. 19).

A presente pesquisa buscou principiar uma investigação necessária e mais consistente sobre os processos de criação artística e técnicas artesanais elaborados por duas comunidades indígenas da etnia Potiguara: Catu dos Eleotérios e Sagi Trabanda, situadas na região do litoral sul do Rio Grande do Norte. Apesar de identificarmos a existência de uma variabilidade de práticas artesanais de procedência étnica nas referidas comunidades indígenas, verificamos uma insuficiência de informações acerca destes ofícios, resultante da ausência de pesquisas e invisibilidade étnica relegada a essa população (CAVIGNAC, 2005). Os trabalhos de Silva (2007) sobre o Catu e Nunes (2015) sobre o Sagi, estão situados como esforços de pesquisas recentes realizadas no âmbito da antropologia sobre os Potiguaras que vivem no litoral sul do Rio Grande do Norte.

Um fato evidente despertou um incomodo: que não são conhecidos, nem revelados a contento os autores e os saberes implícitos nesses ofícios. As questões seguintes nos chamaram atenção: quem produz esse artesanato? Quais as matérias-primas utilizadas? Como ocorrem os processos de feitura? Quais as tipologias? Quais os espaços de distribuição, comercialização e consumo?

Pensamos que "a cultura material, [relativa a produção do artesanato] está inserida em contextos sócio-ecológico-territoriais e imbricada nas dinâmicas de poder que envolvem

\footnotetext{
3 O termo comunidade é utilizado pelos próprios grupos indígenas do RN, como uma versão
} atualizada do espaço territorial da aldeia. 
sua produção, significação e circulação" (LIMA FILHO e SILVA, 2012, p. 45, grifo nosso). Conforme aponta Lima Filho (2012, p. 47), "no Brasil, nos últimos anos, o tema da cultura material ganhou novo interesse acadêmico relacionando-se aos estudos do patrimônio". Ainda nesse sentido, informações sobre a dimensão simbólica envolvida nessas práticas carecem de um olhar minucioso acerca dos sentidos atribuídos ao artesanato no âmbito interno às comunidades indígenas, e aqueles que as comunidades emprestam externamente (PRICE, 2000). Assim, buscamos registrar as experiências estéticas vivenciadas pelos seus autores e gravadas nos saberes, nas práticas, nos objetos e em sua circularidade.

A pesquisa se justificou pela necessidade de reconhecimento e valorização das culturas indígenas no estado do Rio Grande do Norte, marcadas por uma incômoda invisibilidade produzida pela historiografia oficial, associada às comunidades tradicionais de origem étnicas (CAVIGNAC, 2003). Esse vácuo resultante em uma lacuna não preenchida sobre a cultura e história dos povos indígenas no Rio Grande do Norte, tem motivado projetos de pesquisa e extensão no qual esse trabalho está inserido. O projeto de pesquisa foi motivado pela preocupação com a continuidade e reprodução dos patrimônios étnicoculturais indígenas e de seus saberes tradicionais. Esperamos, com os resultados da pesquisa, como o presente artigo, estimular o acréscimo dos dados sobre essa produção artística, favorecendo sua utilização como recurso didático importante para que estudantes, professores e pesquisadores acessem esses conhecimentos, ampliando a formação estética a partir de um olhar mais aprofundado sobre a diversidade artística e cultural presente no estado do Rio Grande do Norte.

O trabalho principiado durante o segundo semestre do ano de 2016 foi concluído no primeiro semestre de 2017, como um projeto de pesquisa vinculado ao Núcleo de Estudos Afro-Brasileiros e Indígenas (NEABI) do Instituto Federal de Educação, Ciência e Tecnologia do Rio Grande do Norte, campus Canguaretama4. Lideranças potiguaras participam regularmente como representantes externos das reuniões e ações diversas desse grupo. Os quais estiveram de acordo com tema de pesquisa, atuando como mediadores nos primeiros contatos com os artesãos indígenas. O estudo objetivou valorizar o artesanato indígena como expressão cultural no contexto da etnogênese entre povos existentes no Nordeste brasileiro. A metodologia utilizada envolveu a pesquisa bibliográfica e, a pesquisa de campo de caráter etnográfico, fundamentada na observação direta do cotidiano dos artesãos e na realização de entrevistas abertas ou semiestruturadas. Рara o registro das manifestações artísticas locais relacionadas ao tema, foram feitas anotações, fotografias digitais e gravações em audiovisual.

\footnotetext{
${ }^{4}$ Para maiores detalhes das pesquisas realizadas ver a página: <http://nicom.ifrn.edu.br/neabi/>
} 


\section{OS ALICERCES DO FAZER ARTESANAL}

Inicialmente, expusemos aos interlocutores lideranças e artesãos indígenas, o não compartilhamento de juízos de valor que categorizam de maneira desigual e discriminatória os sujeitos, os saberes e os fazeres desvinculados de seus contextos históricos e culturais de origem. Dessa forma, utilizamos ao longo da pesquisa os termos "arte" e "artesanato" como análogos, despojados da rigidez de fronteiras antagônicas e das conotações hierárquicas, em conformidade com as vozes dos autores do Catu e do Sagi para os quais esses limites também ressoam imprecisos, nos posicionamos em conexão ao pensamento da antropóloga Ângela Mascelani (2002): "para a maioria dos artistas populares, arte, trabalho, ofício e artesanato são palavras equivalentes, que qualificam amplamente o gênero de trabalho que fazem". Essa autora analisa as discussões em torno das referidas categorias como não engessadas, passíveis de mudanças, questionamentos, negociações e, na realidade, pouco expressivas para seus autores diante da diversidade de experiências e histórias de vida por eles vivenciadas.

O conceito de "artesanato" aparece internalizado nas narrativas orais dos indígenas potiguaras, referente à cultura material que realizam, vinculada ao cotidiano dos grupos e compreende variadas técnicas de construção de artefatos usados na pesca artesanal com maior ocorrência na comunidade de Sagi-Trabanda (embarcações, remos, redes, armadilhas para capturar camarões, âncoras) enquanto adornos corporais são observados com maior ocorrência na comunidade do Catu dos Eleotérios (colares, brincos, pulseiras e prendedores de cabelo). Outros objetos encontrados atualmente nas referidas comunidades são utilitários ou decorativos feitos de cipós, junco e bambus nativos, escamas de peixe, cabaça, madeira e trançados em crochê, frutos de intercâmbios estabelecidos entre diversos atores sociais indígenas e não indígenas, como por exemplo, ação indigenista e de contextos socioculturais diversos, nesse processo de hibridação de conhecimentos, materiais, usos e sentidos são partilhados e recriados na dinâmica da vida social. Compreendemos igualmente o artesanato como um processo cultural, considerando além dos objetos, as relações sociais estabelecidas para a sua produção (CANCLINI, 2003).

As referências para a criação do artesanato indígena potiguara atualmente são muito diversas, os objetos ocasionalmente são configurados a partir de tradições locais de cada grupo; em outros momentos referenciados com base nos núcleos familiares das comunidades. Algumas práticas são ativadas pela memória coletiva e expressas pela oralidade, além disso, os grupos reconhecem a realização de intercâmbios de saberes e materiais com "os parentes" Potiguaras da Baía da Traição (PB); além de acionarem como importante referência na produção de artesanato, os indígenas da etnia Fulniô (PE). 
Os objetos desenvolvidos nas práticas de artesanato são atualizados pela forte proximidade com técnicas de artesanato hippie, no caso dos indígenas do Sagi que com frequência mantem contato com viajantes em busca de belas paisagens de sol e mar carregando suas produções artesanais de adornos corporais (brincos, pulseiras etc); no contato com lojas especializadas de comércio regional; pelas exigências do turismo ou por imagens disponíveis na internet. Importa frisar que não reconhecemos os produtos artesanais encerrados friamente em sua materialidade, isolados, desconectados da vida de quem os realiza ou de quem com eles de alguma forma socialmente interage (INGOLD, 2012).

Além disso, enxergamos a possibilidade de construirmos leituras distintas a partir de um mesmo objeto, reconhecendo-o como artesanal quando resultante de processos de produção prioritariamente advindos do exercício da manualidade e, como artístico, quando, nele, são ressaltados os diversos aspectos formais, estéticos, simbólicos, os sentidos e valores culturais que abrange. Compreendemos os objetos artísticos/artesanais adaptados e inseridos à vida contemporânea, sujeitos a processos de mudanças, portanto, desprovidos de um olhar que em nome de uma suposta "tradição" congelada que os considere como estáticos e inalteráveis, produzida por uma tradição de pesquisa mais folclórica feita na segunda metade do século XX, muito influenciada pelos trabalhos de Luís da Câmara Cascudo. Os apreendemos sim como representativos de múltiplos contextos e valores culturais, não desvinculados das relações de mercado, porém, não limitados à simples condição de mercadorias. Distintos em seu fazer dos objetos industriais, produzidos em larga escala num breve espaço de tempo por maquinarias programadas para unificar e delimitar a intervenção humana. Os objetos nascidos de processos artísticos ou artesanais, possuem irregularidades formais, tempos específicos de elaboração, marcas culturais singulares que os particularizam e, ao contrário de significar defeitos, anormalidades ou prejuízos, os diferenciam e valorizam (LIMA, 2010).

Entre os indígenas do Catu e Sagi, os objetos artesanais estão presentes e integrados à vida diária das comunidades e também em importantes momentos festivos, onde se expressam fortes valores e tradições comunitárias, tais como a Festa da Batata, realizada no mês de novembro em Catu dos Eleotérios e a Festa do Milho celebrada durante o mês de junho no Sagi-Trabanda. Tais objetos permitem o nascimento da experiência estética, que se soma ao conhecimento científico na produção de sentidos para a realidade. Enquanto este último dispõe de um método que traduz a realidade em enunciados empiricamente verificáveis, as linguagens artísticas, sem contradizer a ciência ou a lógica formal, mas suplantando-as pela potência dos sentidos corporais, desvela-nos outras paisagens epistemológicas. Tal desvelamento se opera por uma imersão no mundo que vai além da manipulação das coisas. Trata-se, ao invés, de um habitar, de um imbricamento com 
ele (MERLEAU-PONTY, 2011). Recorrer à produção artesanal da comunidade indígena local é um modo de abordagem do real que nos permite friccioná-lo e colocá-lo ao avesso, com vistas a produzir sentidos antes não vislumbrados. Estes sentidos outros são possíveis não graças ao fato de termos um corpo, mas de o sermos e, por isso, produzirmos sentido no e com o mundo que nos circunda, inclusive com os objetos naturais ou fabricados (MERLEAUPONTY, 2011).

Deste modo, nossa pesquisa se insere em contexto de resurgimento étnico, onde as expressões culturais dos grupos indígenas, especialmente sua produção artesanal, passam a ser acessadas pela população geral não indígena, necessitando ser reconhecida enquanto obra de valor artístico, assim como, consideradas patrimônio cultural de origem étnica.

\section{OS NOVOS ARTEFATOS DE LUTA: AFIRMAÇÃO E MOBILIZAÇÃO POLÍTICA}

O território que hoje forma o estado do Rio Grande do Norte foi palco de um dos maiores conflitos étnicos do período colonial, a chamada Guerra dos Bárbaros (LOPES, 2005). Contada sempre pela versão dos vencedores, os quais impuseram a ideia de extermínio para as populações nativas. Contudo, pesquisas recentes comprovam ter havido um amplo processo de resistência (CAVIGNAC, 2012). Essa imposição de uma versão da história, explica por que a chamada Guerra dos Bárbaros não é reconhecida como um dos maiores movimentos de resistência indígena da historiografia do país. As regiões que hoje formam Arês, Vila Flor, Cunhaú, Nísia Floresta, Extremoz e Ceará-Mirim eram as missões mais importantes da época colonial (LOPES, 2005). Confirmando assim, a presença de grupos étnicos que foram invisibilizados ao longo de séculos, perseguidos e marginalizados socialmente.

No Brasil do século XXI, as populações indígenas têm dificuldade em fazer valer seus direitos num país que declara em alto e bom tom sua pluralidade cultural. Ainda pior, são vistos como impedimento ao progresso ou são ignorados pela grande parte da população, subjugados a um passado heroico (CAVIGNAC, 2012).

Desde o final dos anos 1990, com a comemoração dos 500 anos do Brasil e logo em seguida durante a campanha da fraternidade com tema dedicado aos povos indígenas, o debate sobre as questões étnicas tomaram a esfera pública do RN, inicialmente com apoio de ação indigenista por meio de iniciativas individuais e de instituições como a igreja católica, universidade e órgãos de cultura do governo estadual. A partir de fins de 2005 as lideranças indígenas do Catu participaram da audiência pública - Comunidades Indígenas do RN: afirmação de suas identidades - assumindo o protagonismo na reivindicação por direitos sociais. O contexto histórico que principia a visibilidade social dos povos indígenas no Rio Grande do Norte se consolida com audiência pública citada, realizada na Assembleia 
Legislativa na cidade de Natal, quando os grupos indígenas reivindicam sua identidade étnica como legítima. Essa atitude de afirmação étnica significou um marco no âmbito da esfera pública do Rio Grande do Norte protagonizado pelos grupos indígenas. Desde o seu aparecimento público, a história dessas populações tem sido escrita mediante sucessivas ações coletivas, objetivando garantir progressivamente o reconhecimento definitivo de sua identidade étnica como um grupo com valores culturais específicos em relação de equidade com outros grupos sociais.

A produção da arte indígena pode ser pensada como integrante de um saber próprio tradicional; expressão cosmológica; instrumento de valorização identitária; e mesmo permeada pela demanda do mercado, atendendo a uma demanda concreta de mercado (ARRUTI et al, 2014). Práticas artísticas, dentre as quais, a pintura corporal, é recuperada simultaneamente ao contexto de reafirmação étnica dos potiguaras e sua crescente participação no movimento indígena nacional, a partir de fins da década de 1990 e inicio do ano 2000.

Percebemos que pintar o corpo é prática significativa que precisava ser ativada entre o grupo e não se restringe à simples decoração da pele, pois, a pintura é plena de elementos simbólicos. "É nossa segunda pele", afirma a professora Claudiane Soares. "Pintados nos sentimos parte da natureza", "a pintura expressa nossa admiração pela natureza", comentam respectivamente os artesãos Meiriane e Graciliano. "Também nos pintamos para receber as pessoas e expressar nossa felicidade", diz o coletor de mangabas Erivanildo ${ }^{5}$. Segundo Canclini (2003), dessa forma pode-se entender a inserção da obra de arte em um determinado meio social.

De maneira geral, pinturas com cores fortes (o rosto pintado de negro), são feitas para momentos de batalhas, protestos, luto e resistência. Cores mais suaves significam felicidade e vida. Os principais motivos são a cobra, a colmeia, a borboleta, o jabuti e o peixe, representações gráficas assimiladas pelos habitantes do Catu. De acordo com os indígenas do Catu, os parentes Potiguaras da Baía da Traição na Paraíba, utilizam outros motivos como a malha da saramanta (espécie de serpente), as folhas da jurema e os caminhos dos ventos. Como matérias-primas, utilizam as sementes de urucum trituradas para a obtenção da cor vermelha ou alaranjada, o sumo do jenipapo e o carvão para a cor preta, o amarelo forte é proveniente da resina da árvore gulandi ${ }^{6}$. Pintam-se usando pincéis industrializados, palitos de madeira, palha de coqueiro, penas e os dedos.

\footnotetext{
${ }^{5}$ O trabalho organizado pela antropóloga Lux Vidal (1998) sobre grafismos inscritos nos corpos de povos indígenas, evidência a importância estética que as formas das figuras modeladas possuem, remetendo assim a um universo social e cosmológico desses povos.

${ }^{6}$ O guanandiou jacareúba é uma árvore brasileira da família Calophyllaceae. Gulandi é mais um dos seus nomes populares.
} 
Figura 01: Crianças indígenas realizam pintura corporal na Escola João Lino da Silva durante a Festa da Batata, Catu dos Eleotérios, 2015

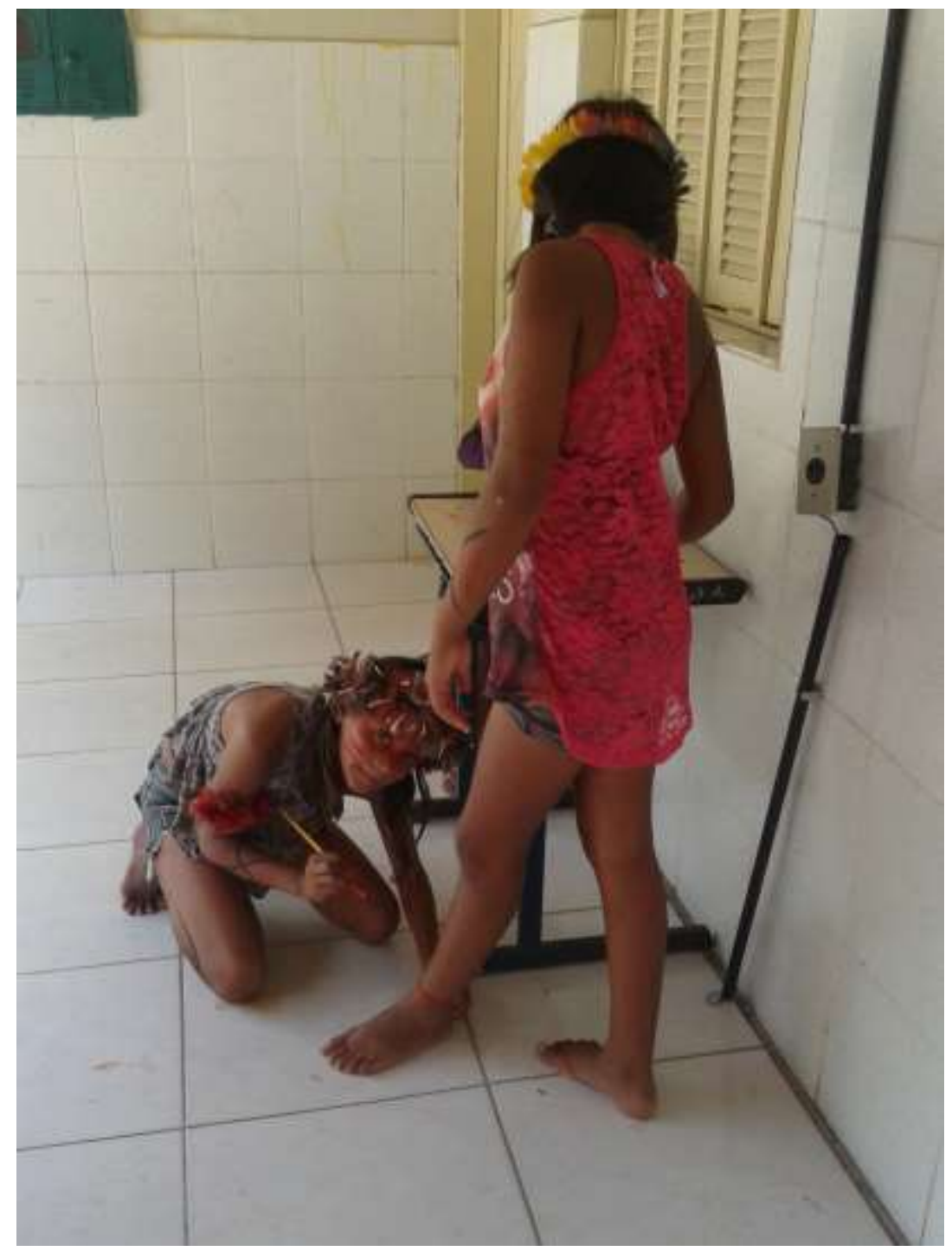

Durante a realização da pesquisa, observamos dentre os participantes, atribuições ao artesanato como elemento simbólico e representativo da cultura indígena, utilizado para materializar tradições e identidades especialmente quando há espaço para exposições dos objetos aos visitantes não indígenas em eventos internos e externos às comunidades. Nessas ocasiões predominam os objetos de pequenas dimensões, de baixo custo e mais fáceis de transportar como arcos, flechas, miniaturas de zarabatanas e enfeites corporais, instrumentos musicais percussivos, quando expostos em eventos públicos limitam-se costumeiramente à exposição e venda dos objetos. Os outros objetos como a cestaria utilitária e os instrumentos de pesca, são suprimidos, apesar de serem confeccionados com objetivos de contextos usuais como a pesca e o transporte de materiais. 
Pensamos que em processo de investigação, parece existir um reforço intencional ou involuntário na apresentação de um grupo de objetos mais facilmente identificável como "indígenas" em detrimento de outros categorizados como mais cotidianos, regularmente encontrados em outras comunidades rurais ou pesqueiras.

Figura 02: Venda de artesanato indígena na Festa da Batata, Catu dos Eleotérios, 2015

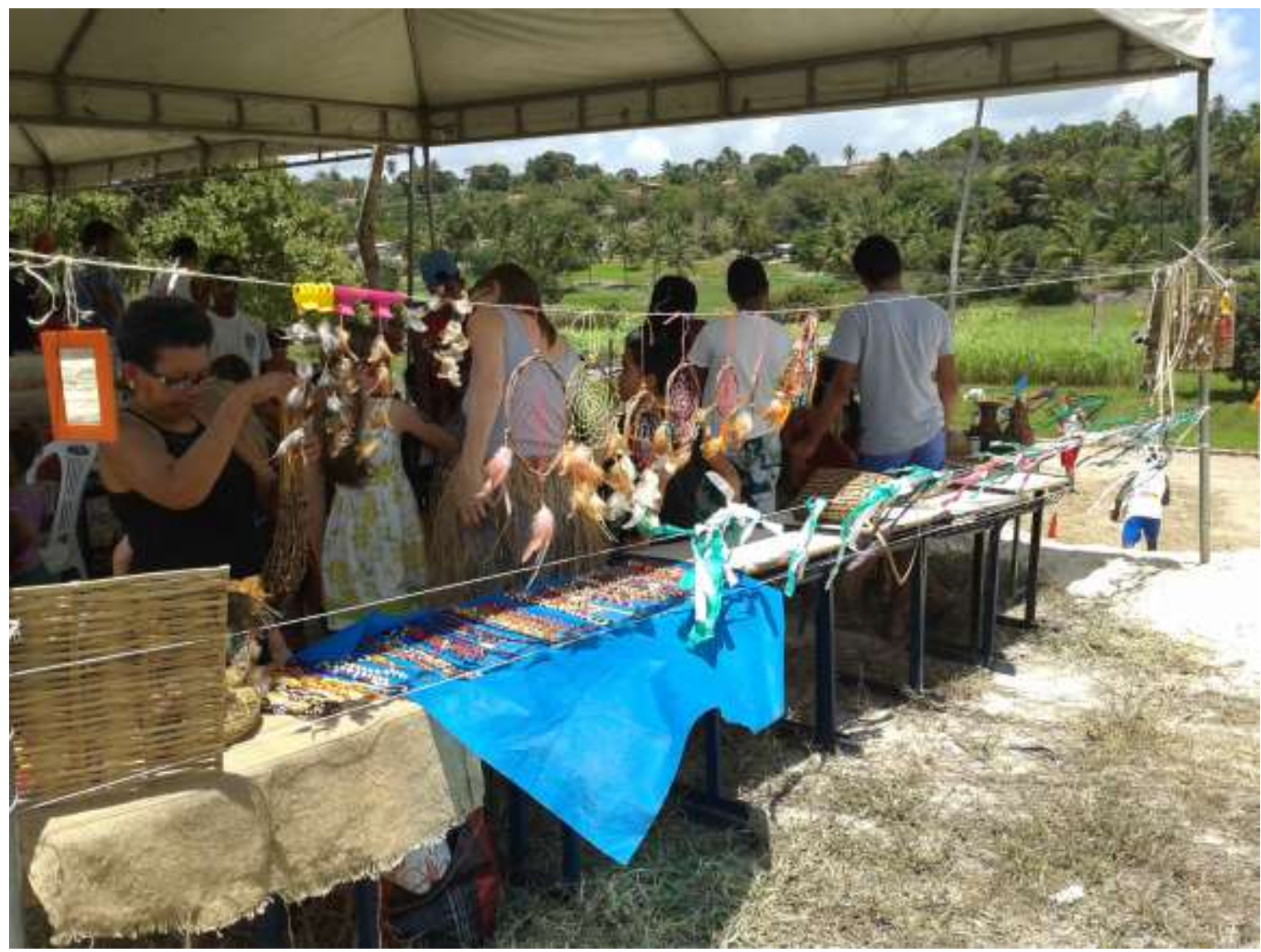

Observamos, sobretudo entre artesãos que reconhecem no artesanato uma nova possibilidade de trabalho, a busca de estratégias para a distribuição de sua produção em contextos distintos das comunidades nas quais residem, deste modo, os objetos já foram divulgados em eventos específicos para mostra e comercialização de artesanato como a Feira Internacional de Artesanato (FIART), realizada anualmente no Centro de Convenções de Natal, capital do estado; em unidades do Instituto Federal do Rio Grande do Norte (IFRN) e da Universidade Federal do Rio Grande do Norte (UFRN), além de parques públicos sediados em Natal como o Parque das Dunas. Nessas ocasiões, percebemos uma ênfase em objetos de pequeno porte para facilitar o transporte e o consumo a preços mais acessíveis e, curiosamente, uma seleção (involuntária ou intencional) que muito os aproxima de um imaginário popular idealizado sobre o ser indígena. Alimentando esse imaginário, alguns artesãos intencionalmente se enfeitam com cocares, brincos e colares para o momento das vendas, produzidos para essa ocasião, além dos enfeites corporais como brincos, colares e 
pulseiras, artefatos como instrumentos de caça são miniaturizados, decorados, destituídos de sua função original e resignificados simbolicamente como souvenirs ou brinquedos.

Em ambas comunidades, são encontrados e produzidos brincos, colares, pulseiras, prendedores de cabelo, roupas de crochê, miniaturas de arcos e flechas e os saiotes, estes últimos, identificados como objetos utilizados no ritual do Toré7, não são comercializados. O ritual do Toré ocorre em momentos públicos e fechados a depender da ocasião e representa através das músicas e da dança um importante instrumento de afirmação étnica. $O$ artesanatos utilizados no Toré são produzidos com autonomia pelos próprios indígenas. O trecho de uma música tocada e dançada durante o ritual exprime essa importante relação: "Quero ver quem é que acaba, o resto da empeleitada".

Um dos significados atribuídos a categoria nativa "empeleitada" é que pode ser traduzida enquanto uma tarefa que demanda maior tempo e dedicação para ser realizada. A expressão 'empeleitada', enquanto categoria nativa, implica em tarefa assumida e na qual o regime de trabalho requer um tipo maior de autonomia para ser realizada, reforçando nossa ideia de que as práticas artesanais possuem um tempo diferenciado compreendido a partir do contexto sociocultural especifico da etnia Potiguara.

Assim, podemos pensar que todos os objetos materiais produzidos são frutos de trabalho com tempos sociais específicos para se concretizar. Por exemplo, Lygia Sigaud (1979), nos faz refletir sobre trabalhadores rurais no interior de Pernambuco ao mostrar inovação no que concerne os estudos sobre o universo rural. O trabalho e as festas são marcas presentes no mundo rural das populações que foram englobadas em categorias genéricas como agricultores ou trabalhadores rurais.

Os espaços de comercialização dos demais objetos são a venda direta nas casas dos artesãos, em eventos comunitários e naqueles inseridos em circuitos turísticos na capital, região de Barra de Cunhaú (distrito costeiro pertencente ao município de Canguaretama) e na divisa natural do Rio Guaju, entre os estados do Rio Grande do Norte e da Paraíba. Nos últimos anos, parte deles estão sendo apresentados como elementos identitários significativos aos grupos de visitantes que se dirigem ao Catu para, a partir da Escola Indígena João Lino da Silva, cumprirem um roteiro turístico pedagógico organizado pela própria comunidade destinado a grupos de estudantes dos ensinos fundamental, médio e superior, constituído por trilhas nas matas da região, oficinas do idioma Tupi e de pintura corporal, almoços e a degustação de alimentos tradicionais como os beijus de mandioca

\footnotetext{
${ }^{7}$ O Toré/Torem é um dos principais rituais sagrados dos povos indígenas do Nordeste (VALLE, 2005; GRUNEWALD, 2004) é atualmente uma prática conhecida e presente na maioria das coletividades que se reivindicam como indígenas (SOLER, 2012).
} 
mole8, por intermédio dessa experiência, são compartilhados conhecimentos sobre o modo de viver indígena Potiguara, incluída nesse momento, a venda do artesanato transforma-se em oportunidade para geração de renda e reafirmação do reconhecimento étnico, em um cenário processual ocorrido na arena política por meio de disputas simbólicas e materiais.

\section{O SABer e fazer a ARTE Potiguara em CATU e SAGI}

Às margens do rio Guaju, circundada por uma reserva de mata atlântica, por plantações de cana de açúcar e banhada pelo oceano atlântico, encontra-se a aldeia de SagiTrabanda. Os potiguaras da aldeia Sagi-Trabanda, localizada no município de Baía Formosa, Rio Grande do Norte, organizam-se politicamente desde o início da década de 2000. No local, residem oitenta e duas famílias (cerca de duzentos e cinquenta e sete indígenas) que se afirmam indígenas e são reconhecidas pelo Estado. Os indígenas do Sagi guardam memória de antepassados que habitam o local há pelo menos dois séculos. Os potiguaras do Sagi, de maneira recorrente, fazem referência a "parentes" e antepassados que teriam vindo de aldeias da Baía da Traição e se estabelecido no local. Interessante perceber a importância dessa memória de fluxo/movimento, estabelecida entre os indígenas, unidos pelo pertencimento a um passado que possui uma mesma origem étnico-territorial, Potiguara.

Situados no vale do rio Catu, circundados por plantações de cana de açúcar e pela Área de Proteção Ambiental - APA Piquiri-Una, se encontra a aldeia Catu dos Eleoterios. Afirmando-se indígenas potiguaras do Catu e vivendo na comunidade, existem ao todo, cento e setenta e três famílias (aproximadamente novecentas pessoas). O rio Catu divide os municípios de Canguaretama e Goianinha. As lideranças do Catu são as mais antigas no processo de afirmação e reconhecimento étnico no estado do RN. Vivem majoritariamente de atividades agrícolas com cultivo da batata, macaxeira e hortaliças que são comercializadas nas feiras e de benefícios sociais do governo federal. De modo sazonal, realizam práticas de coleta de mangaba e a pesca no rio Catu. Na comunidade está situada a primeira escola indígena reconhecida e credenciada pelos órgãos do Estado. A saúde dos indígenas é realizada por meio de acompanhamento regular realizado pela Secretária Especial de Saúde Indígena - SESAl. Igualmente acompanhados por uma Coordenação Técnica Local da Fundação Nacional do Índio - FUNAl, o acesso à terra coletiva ainda se constitui enquanto um processo de reivindicação para ambas as comunidades.

Nos primeiros diálogos da pesquisa com as lideranças locais, soubemos da existência de aproximadamente 60 pessoas trabalhando com artesanatos diversos, numa estimativa de 20 pessoas no Catu e 40 em Sagi-Trabanda. Um número muito significativo para lugares que

\footnotetext{
${ }^{8}$ Mandioca deixada de molho na água para amolecer e fermentar, também conhecida como carimã, massa podre ou massa puba. (CASCUDO, 2004; LODY, 2005).
} 
não são conhecidos no cenário norte rio-grandense como centros produtores de artesanato. O trabalho é desenvolvido por homens e mulheres, entre jovens e adultos, que utilizam matérias primas locais mescladas a outras adquiridas no comércio popular de cidades próximas e da capital. No contexto atual da pesquisa, identificamos um total de 35 nomes de artesãos atuantes e residentes no Catu e no Sagi.

Nas duas aldeias, observamos um vastíssimo conhecimento sobre os recursos naturais existentes em seus respectivos territórios como tipos de sementes e frutos (olho de pombo, sapucaia, mamona, cabaça, cuité, mucunã, pereiro, aguaí, panelinha), fibras vegetais (taboca ou titara, cipó canela, cipó de chão, cipó maracujá, junco, sisal), resinas e pigmentos naturais (jutaicica, leite de bananeira, urucum, jenipapo), madeiras (angola, mangue branco, pau mulato, umburana, bambu, carnaúba, imbiriba, dendê, cajueiro brabo, louro, piquiá), fluxos d'água (Rio Catu e Rio Guaju), composição de terras (paú, tabuleiro, toá, "barro de loiça", tabatinga), animais da fauna nativa como aves (coruja, corujão, gavião, marreca, carcará, bem-te-vi, nambú, rolinha, pai-gonçalo, seriema, zabelê, juriti), mamíferos (tamanduá, raposa), peixes e crustáceos (camarão, serra, camurupim, pescada, pescadinha, cação, tubarão lixa), tais singularidades determinam o feitio de objetos específicos, adequados às realidades culturais e ambientais dos seus habitantes.

No Catu, predomina o trabalho com a agricultura de subsistência e atividades extrativistas, sobretudo o plantio da batata-doce e de hortaliças como cebolinha, coentro, alface, além de frutíferas diversas e da coleta sazonal da mangaba. No Sagi, a proximidade do mar, os manguezais, as embarcações expostas à frente das casas e as redes de pesca estendidas nos cercados, quintais ou alpendres, são reveladores de uma notória tradição pesqueira, ilustradas por armadilhas para capturar camarões, figuras de cavalos marinhos e tartarugas trançados em cipós nativos, utilitários de quenga de coco, cortinas de escamas de peixe, "baiteiras" (pequenas embarcações), remos, âncoras, além das redes de pesca com tramas variadas e adequadas à diversidade de tamanhos dos pescados.

Percebemos noutros objetos, apesar de serem confeccionados artesanalmente, a atribuição de diferentes sentidos, são peças mais utilitárias e que não são destacados nas exposições e na comercialização como "indígenas", são exemplos os utilitários em geral, peças de cestaria como os balaios, samburás, instrumentos de caça, de pesca e outros utilizados nas construções de casas como as "desempoladeiras" usadas para alisar o reboco das paredes. Entretanto, paradoxalmente, esse artesanato é percebido pelos potiguaras como indígena justamente por estarem associados às práticas cotidianas usadas para a sobrevivência, diferente da categoria local "artesanato de enfeite" que compreende, em sua grande maioria, os adornos corporais, utilizados em momentos festivos ou de afirmação política. Estes, são apresentados como lembranças para demonstrar a cultura potiguara aos 
visitantes que por sua vez, os consumem por corresponderem a certo imaginário popular sobre o "ser indígena" marcando percepções distintas sobre os objetos.

Como materialidades, encontramos o uso da taboca (espécie de bambu nativo), cipós, madeiras e sementes variadas, argila, quengas de coco, penas de aves nativas e domésticas, plumas tingidas artificialmente, contas de plástico, conchas marinhas, linhas de algodão para crochê, cabaças, nylon e chumbo.

\section{A ARTE NA MEMÓRIA: OFICIO CERAMISTA NO CATU}

Na realidade pesquisada no Catu, verificamos apesar de atualmente não mais existir a produção compreendida no território da aldeia, uma memória muito viva entre seus habitantes sobre a cerâmica utilitária e lúdica, por essa razão, começamos a desenvolver registros dos relatos sobre as formas e os usos dos objetos de barro, seu processo de feitura (modelagem, decoração e queima), transporte e venda nas feiras livres de Canguaretama e Goianinha a partir das lembranças da família da ceramista Júlia Ribeiro, ativa na aldeia até fins da década de 1970.

Apenas recentemente, identificamos a existência de mulheres ceramistas pertencentes a aproximadamente quinze famílias originárias de Canguaretama e residentes no bairro de Areia Branca, situado nas imediações de um dos acessos ao Catu. Modelar o barro nesta região sempre foi atribuição feminina, ao homem cabia apenas obter a lenha, auxiliar na queima, no transporte ou nas vendas. Uma de suas derradeiras representantes em atividade, a senhora Maria de Fátima de Barros, esporadicamente desenvolve a elaboração da louça, precarizada nos últimos anos pelo amplo acesso dos consumidores a produtos industrializados, sobretudo em plástico e metal, substitutivos daqueles inicialmente produzidos em barro e também pela ausência de incentivos e pela fragilidade da saúde da ceramista.

Considerando o processo de feitura, as ferramentas, a aparência e os usos dos objetos, a prática da cerâmica utilitária na região de Canguaretama transparece forte herança indígena, o conhecimento e o saber-fazer foram incorporados e persistem na população de algumas comunidades, a prática da cerâmica manual representa um desses exemplos. No repertório do saber fazer das ceramistas de Canguaretama, município onde a comunidade do Catu está situada, eram confeccionadas panelas, potes, jarras d'água, cuscuzeira, cabaça (quartinha), torrador de café, caco para fazer beiju, cofrinho ou milhaeiro em forma de pato, jarro de plantas, pratos, tigelas, alguidares, além da louça lúdica destinada às meninas para a brincadeira do cozinhado, ргерагаção simbólica para os afazeres domésticos e ilustrativa do espaço social ocupado pela mulher. 
A redescoberta da cerâmica como prática artesanal, despertou notório interesse entre os indígenas do Catu em recuperar sua produção a partir de oficinas a serem realizadas a princípio com estudantes da Escola Indígena João Lino da Silva. Da mesma forma, lideranças e outros moradores do Catu se dispuseram em readquirir conhecimentos para ensinar às crianças e adultos, um modo de enriquecer o repertório sobre o artesanato potiguara e também de apresentá-lo aos visitantes como símbolo identitário.

Conforme as imagens abaixo, trata-se de uma louça diferenciada em sua aparência quando observamos a olaria artesanal desenvolvida em outras regiões do Estado.

Figuras 03, 04 e 05: Potes produzidos na comunidade da Pindoba I, município de Felipe Guerra, no oeste potiguar. Panelas e caxixis pintados produzidos em Santo Antônio do Potengi, município de São Gonçalo do Amarante, região metropolitana de Natal/RN.

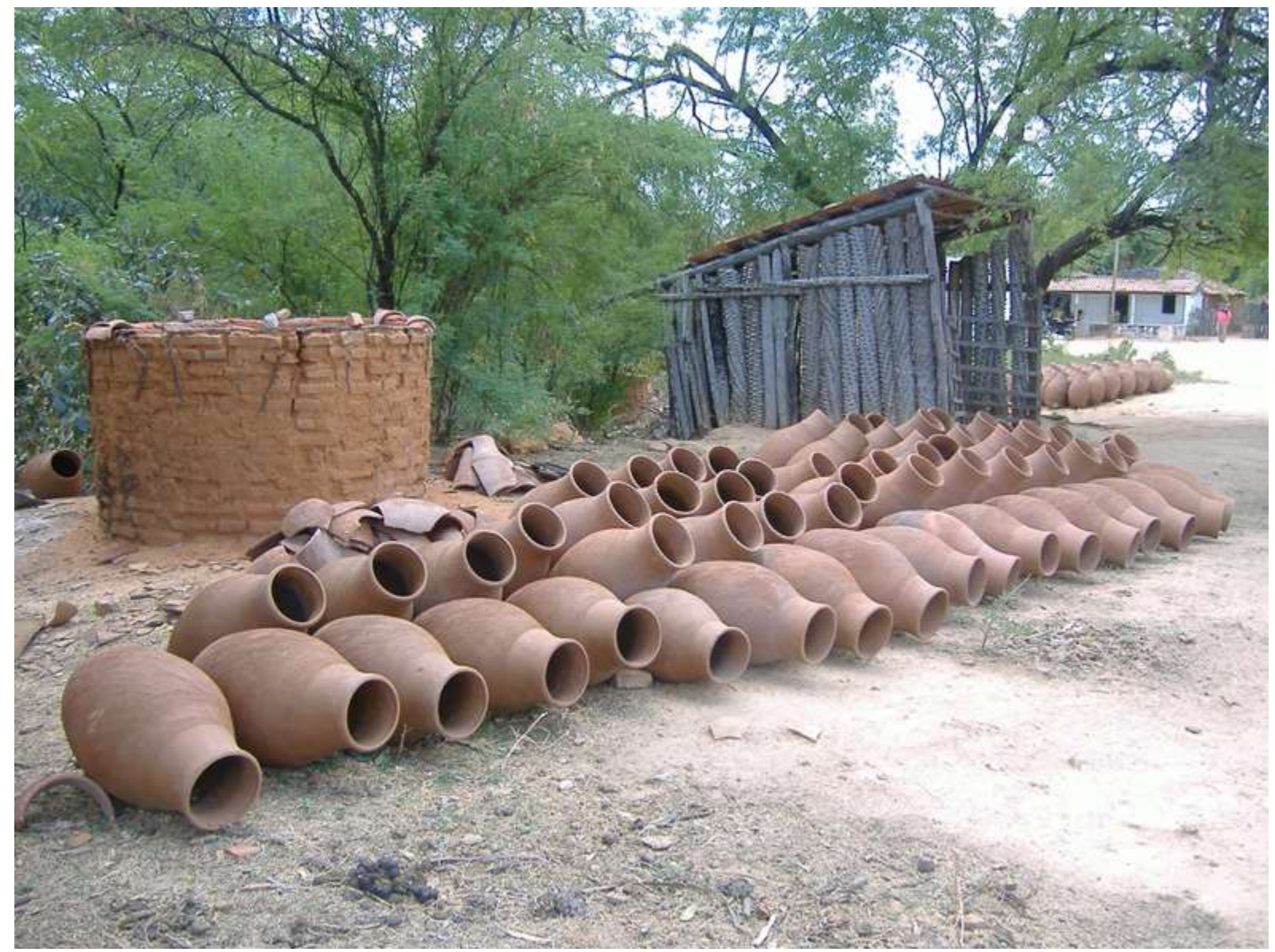



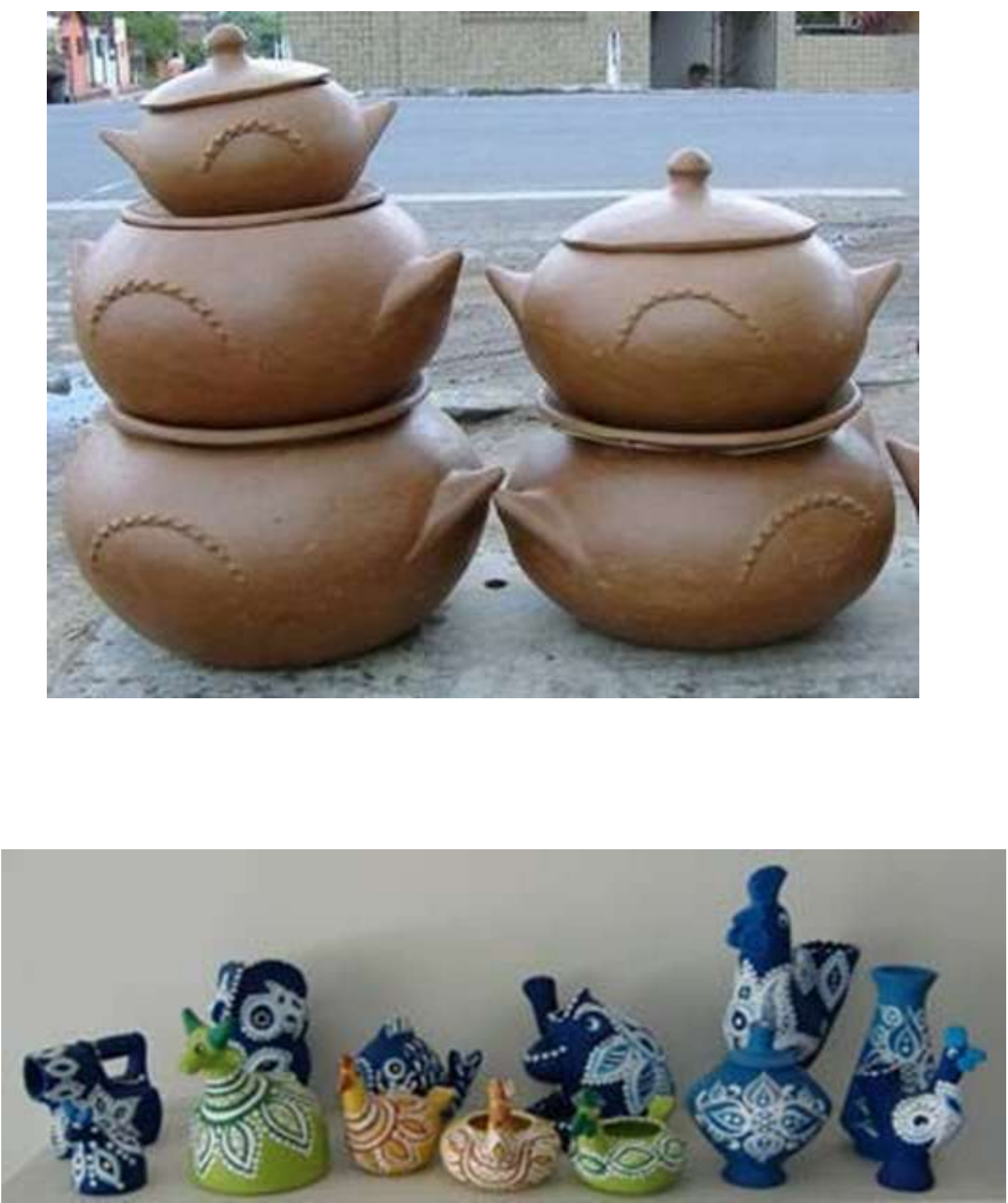
Figuras 06 e 07: Panelas e vasilha decoradas da tradição cerâmica do Catu, 2017.
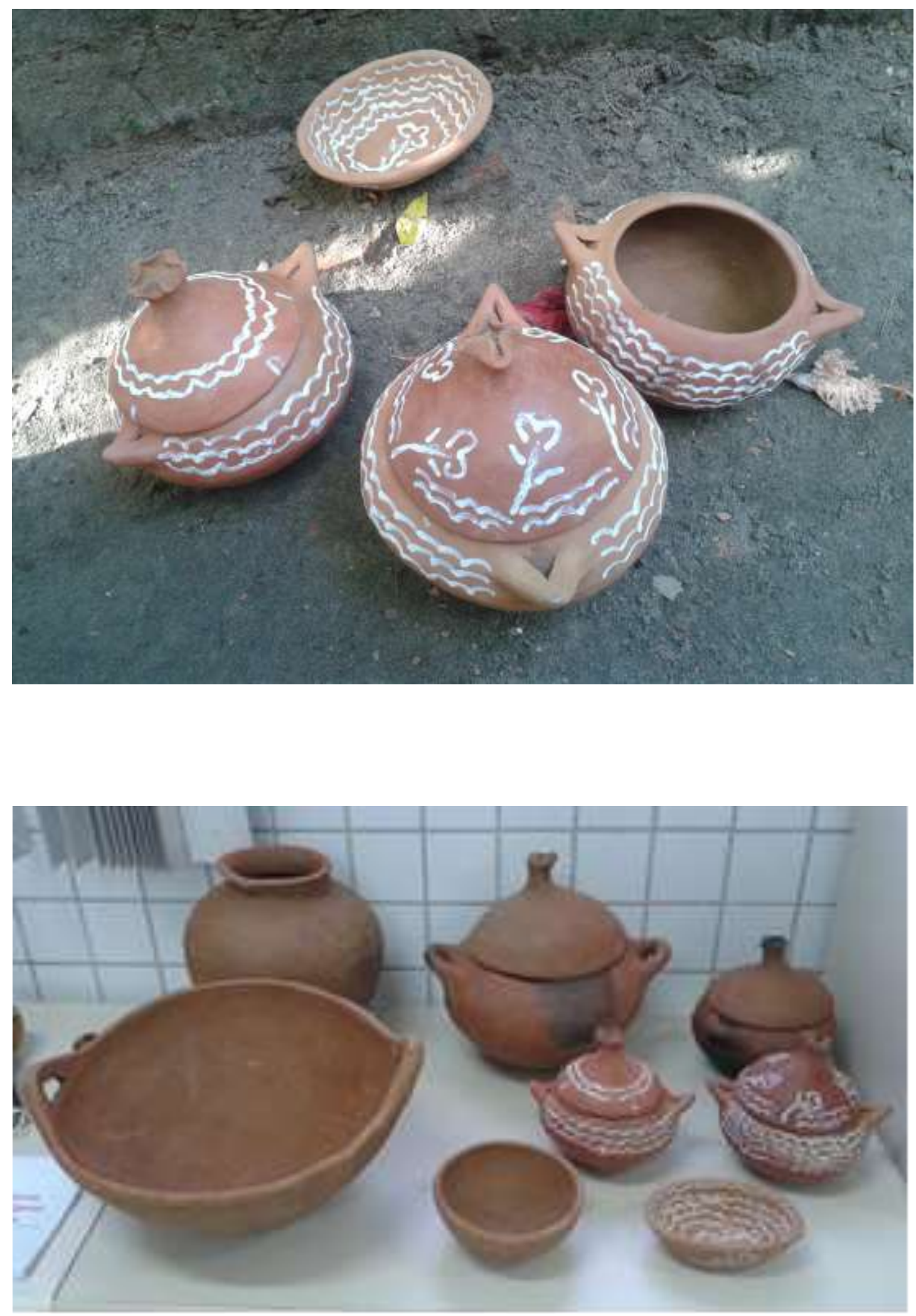

O processo cada vez mais raro atualmente, compreende a coleta da argila em barreiro situado nas imediações da BR 101, posteriormente aguada e amassada com os pés, a modelagem é feita usando a técnica da bola, processo herdado do período neolítico para 
modelagem manual juntamente com a técnica de rolos de argila e do uso de cestos como moldes para enformar recipientes (CHAVARRIA, 1997). A ceramista sentada no chão, utiliza como ferramentas de apoio conchas de cabaça ${ }^{9}$, talos de taboca (bambu nativo) ou de palmeira dendê para a raspagem e pedras de seixo para alisar as peças encimadas numa pequena tábua. Рara a decoração da cerâmica são empregadas duas variações de toá10 (amarelo e branco), o amarelo é aplicado na borda das peças para adquirir coloração avermelhada após a queima, o branco é diluído em água num recipiente e pincelado na cerâmica com palito de coqueiro apresentando grafismos geométricos e florais que identificavam com segurança o trabalho de cada ceramista, com a mesma intenção, eram observadas as variações no formato dos apêndices modelados nos objetos como as asas das panelas.

Figura 08: Padrões gráficos adotados na cerâmica encontrada nas proximidades do Catu, recuperados pelas ceramistas Maria de Fátima e Maicira, Bairro de Areia Branca, Canguaretama, 2017.
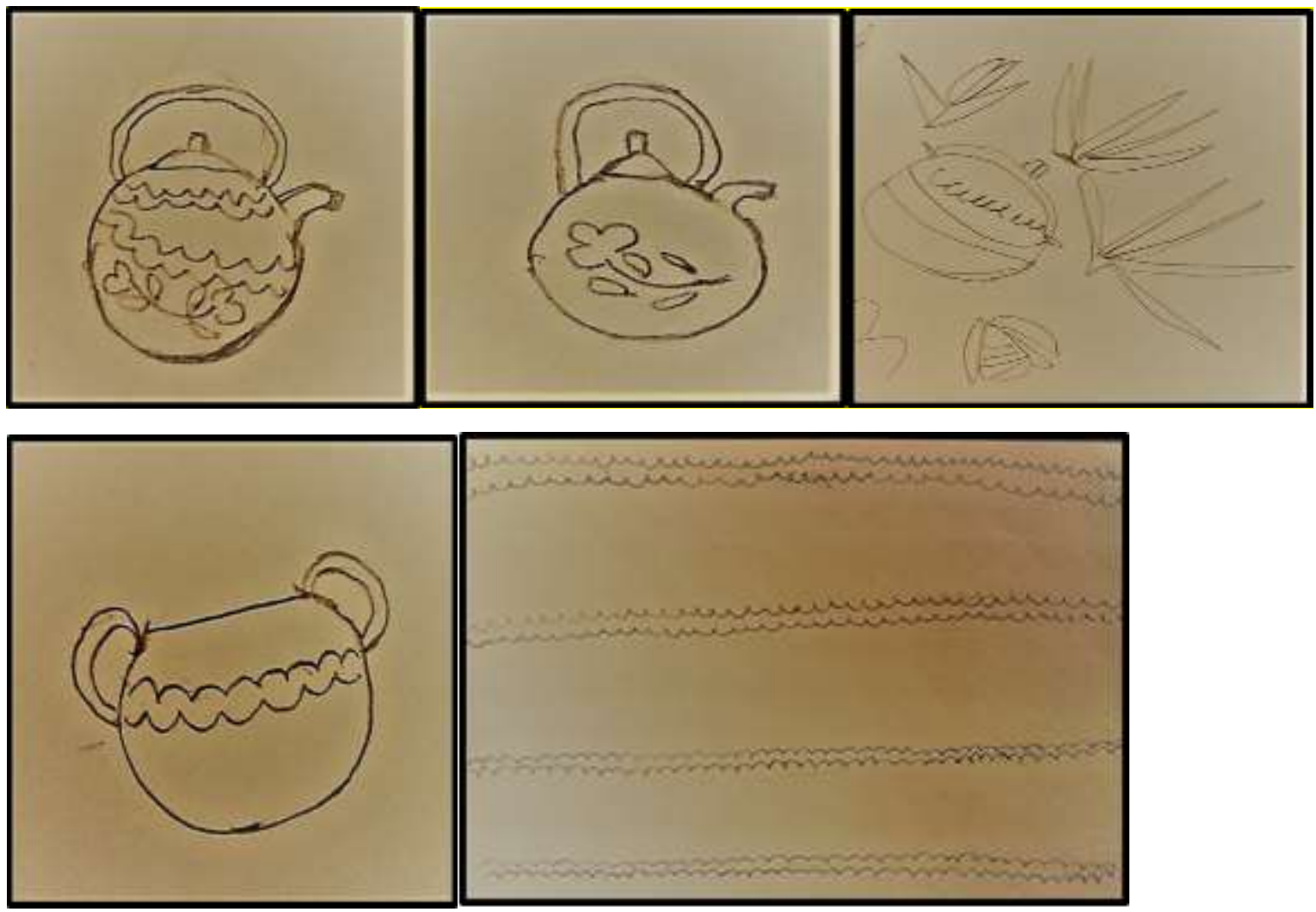

\footnotetext{
${ }^{9}$ Nome popular comum a plantas da família das cucurbitáceas cujas cascas dos frutos, muito duras, são usadas no fabrico de diversos objetos. (HOUAISS, 2001).

${ }^{10}$ Tauá, toá ou taguá é palavra de origem indígena Tupi e significa barro ou argila tingida por óxidos de ferro, encontradas em terrenos erodidos por água corrente. Tinta amarela obtida dessa argila. (HOUAISS, 2001).
} 
Figura 09: A ceramista Maria de Fátima de Barros pintando panelas com toá branco, bairro de Areia Branca, Canguaretama, 2017.

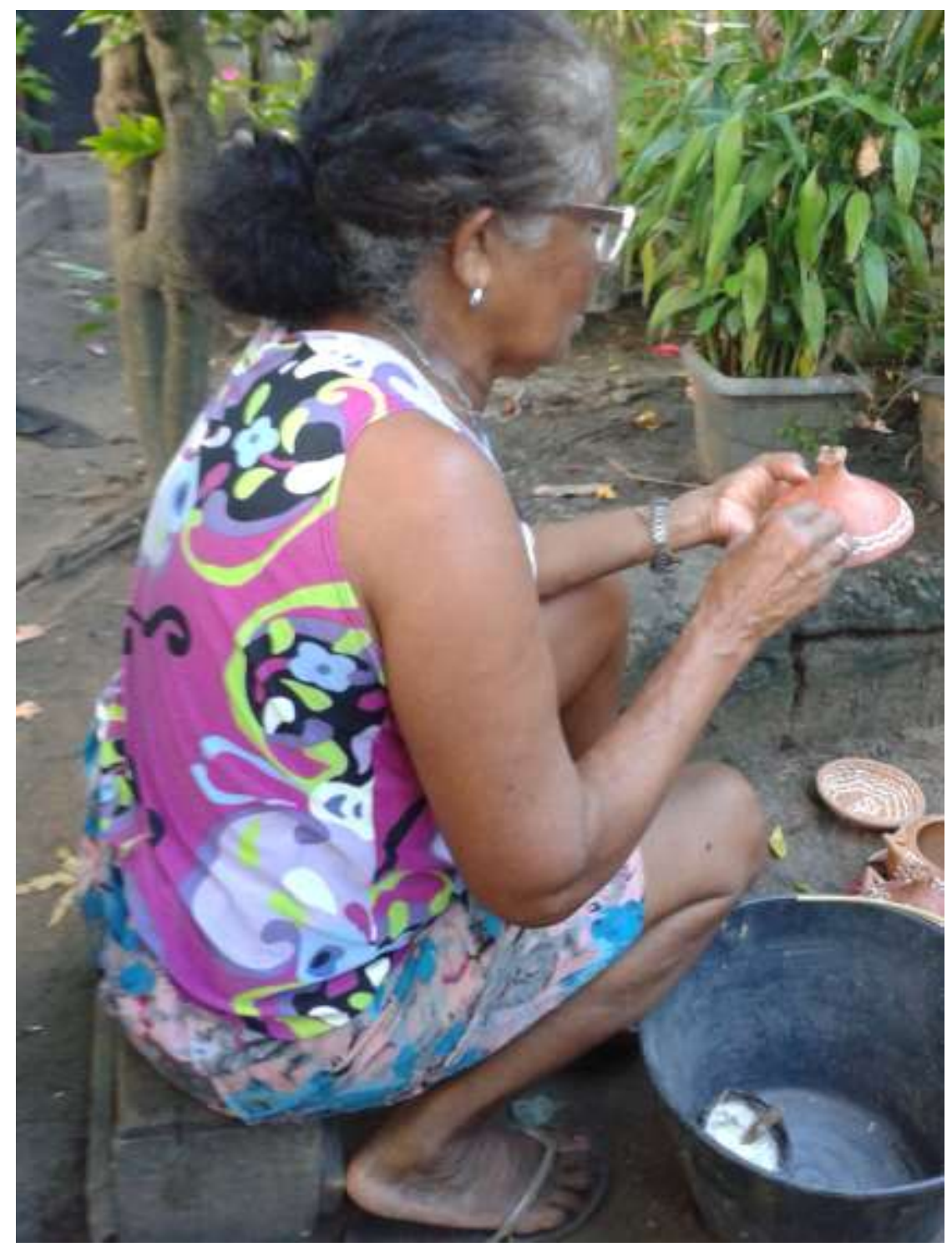

\section{O OFICIO DA PESCA EM SAGI}

A pesca artesanal sempre esteve presente no cotidiano das famílias de SagiTrabanda, é o mar que oferece o complemento da alimentação básica advinda das roças cultivadas nas terras de paús ${ }^{11}$ e na venda excedente de pescados para restaurantes e terceiros. É atividade transmitida por bisavôs, avôs e pais, exclusivamente masculina e, desde os nove ou dez anos de idade, os meninos são iniciados na complexidade de conhecimentos que envolve a formação do pescador. Interessante perceber que a pesca ocupa um lugar central na vida comunitária entre as aldeias dos Potiguaras da Paraíba (VIEIRA, 2010).

\footnotetext{
${ }^{11}$ Local da aldeia onde a terra permanece úmida e se desenvolve a prática da agricultura.
} 
A preparação principia com os banhos de mar para criar a intimidade imprescindivel com o ambiente aquático. Depois de aprender a nadar, começam os passeios de barco próximos à praia para "desembebedar", ou seja, criar firmeza na instabilidade das ondas e evitar os enjôos indesejáveis. O ato da pesca envolve diretamente a construção e o uso direto de diversos objetos artesanais confeccionados para a atividade pesqueira, portanto, esse conhecimento tradicional precisa ser repassado e internalizado para que o jovem pescador obtenha sucesso em sua tarefa. Vencidas as primeiras etapas, o menino enfim já pode colaborar na pescaria ajudando a puxar as redes e a desmalhar os peixes nelas contidos. Para isso, precisa vencer na companhia de um adulto três ou quatro quilômetros mar à dentro numa baiteira, embarcação de pequeno porte, sem motor, muitas vezes sem vela, se deslocando apenas com o auxílio de uma vara e de remos até atingir os pontos ideais de pesca, ensinados pelos mais velhos há gerações. Рara cada espécie ou tamanho de peixe é necessário tramar redes adequadas. As redes de pesca no Sagi são empregadas na captura de peixes serras, pescadas, pescadinhas, camurins, cações e tubarões lixa. O diâmetro das malhas então varia, podendo ser finas ou grossas, saber tramar as redes com segurança representa nova fase de aprendizado, simultaneamente às habilidades de amarrar anzóis e costurar cordas. Como materiais são utilizados nylon, agulha, mordos ${ }^{12}$, cordas, chumbo, bóias e âncoras.

Figura 10: Processo de ensino da produção de redes de pesca no Sagi, 2017

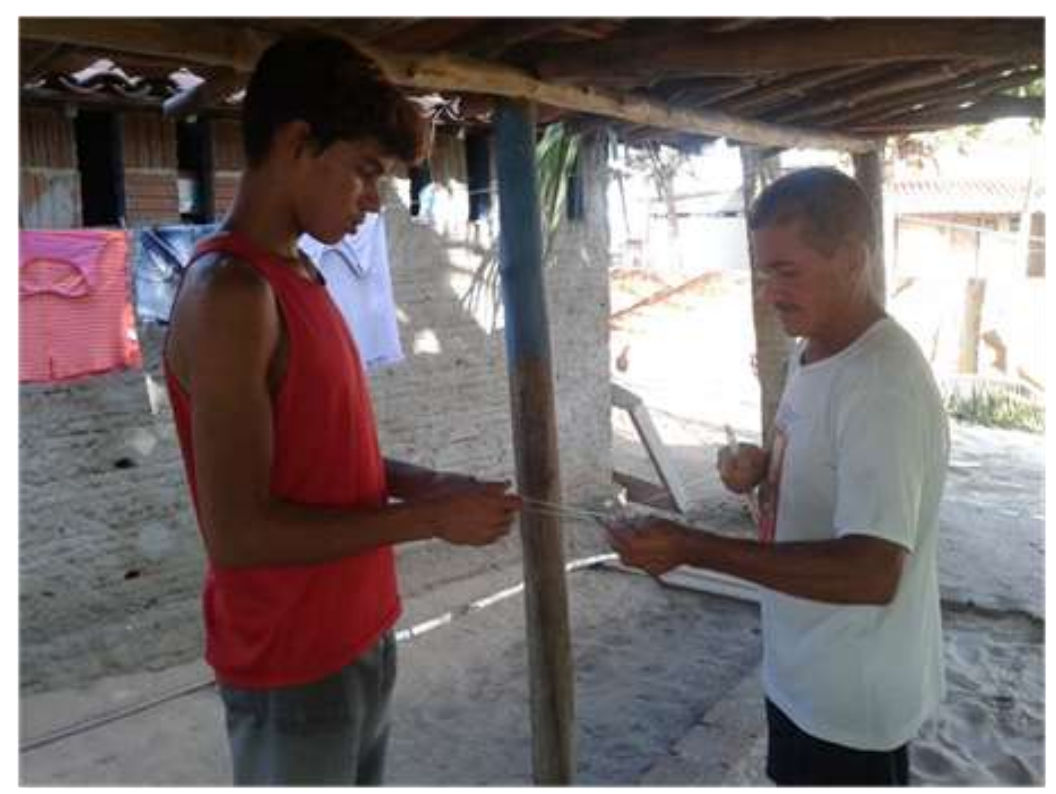

\footnotetext{
12 Por mordos são conhecidos localmente no Sagi instrumentos de medida, de formato retangular, confeccionados em madeira e utilizados para orientar o espaçamento correto das malhas das redes no momento de entrelaçar seus fios. Seu tamanho pode apresentar variações conforme o tipo de pescado que se deseja capturar; para espécies de peixes menores, por exemplo, utilizam-se redes de malha mais fina e fechada elaboradas com um mordo pequeno.
} 
A baiteira é a embarcação mais utilizada na comunidade de Sagi-Trabanda, de pequeno porte, cerca de três metros no máximo, difere da jangada, maior (5 a 6 metros) e mais larga. Possui estrutura muito simples confeccionada preferencialmente com tábuas de madeira louro e piquiá13 ${ }^{13}$ A construção da baiteira também está compreendida no processo de formação do pescador artesanal. Cada um faz a sua, o trabalho começa pelo entalhe e fixação das bordas, não há exatidão de medidas na altura, as tábuas laterais não são retas, largas ao centro, conforme se aproxima das bordas são levemente diminuídas dando-lhes uma discreta aparência arredondada. Sua fixação é feita com pregos em barrotes (mais largos que os caibros), cinco fileiras. O interior do lastro é oco e posteriormente preenchido com isopor para ajudar na flutuação. No primeiro barrote à frente da embarcação, são fixadas cordas para a sustentação do pescador e outra para suster redes e anzóis. Pouco mais à frente do centro da baiteira é montado o banco para velas, acessório utilizado por alguns pescadores para impulsionar a embarcação e minimizar o esforço do uso dos remos. O fundo da baiteira é achatado, quando prontas recebem pinturas.

Figura 11: Apresentação da baiteira e de seus usos no Sagi, 2017

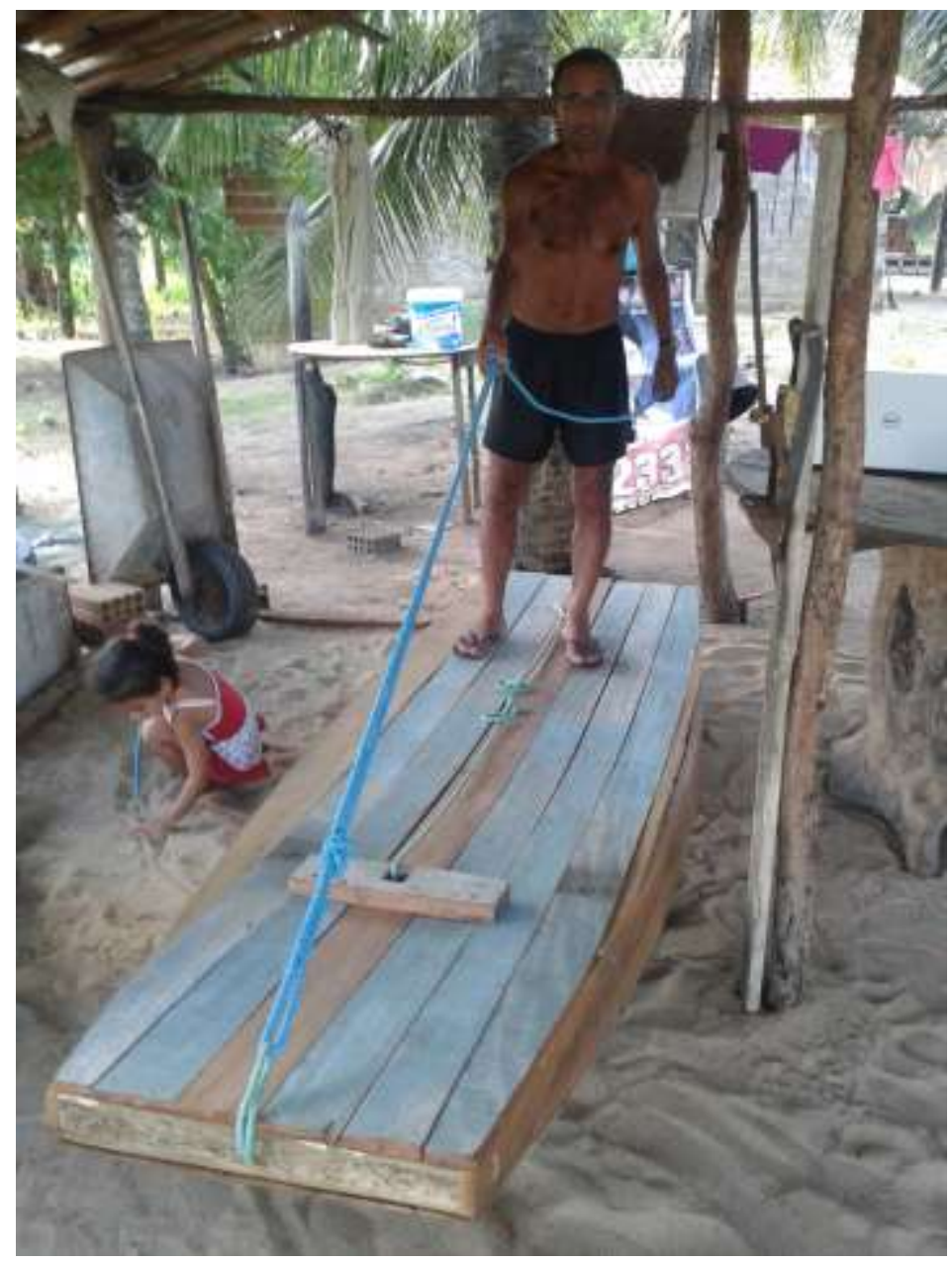

13 Nome científico da árvore: Caryocar villosum (Aubl.) Pers., Caryocaraceae. (Fonte: < http://www.ipt.br/informacoes_madeiras/72.htm> acesso em junho de 2017). 


\section{CONTINUANDO A 'EMPELEITADA'}

Podemos afirmar com base na realidade observada entre os praticantes do artesanato nas comunidades do Catu e do Sagi, ser esta uma prática relevante da etnia Potiguara. Os objetos materiais possuem importante valor simbólico e são valorizados como representativos da cultura indígena, utilizados para materializar tradições e identidades especialmente quando há espaço para exposições dos objetos aos visitantes não indígenas em eventos internos e externos à comunidade. Nessas ocasiões predominam os objetos de pequenas dimensões mais fáceis de transportar: arcos, flechas, zarabatanas e enfeites corporais.

Entretanto, percebemos em ambas as comunidades, a existência de outros objetos que apesar de artesanais, a eles são atribuídos outros sentidos. Como apresentado, trata-se de peças de caráter mais utilitários, incorporadas ao cotidiano e que não são destacados nas exposições e na comercialização como "indígenas", são exemplos os balaios, instrumentos de caça, de pesca e outros utilizados nas construções de casas como as "desempoladeiras" usadas para alisar o reboco das paredes. Destacamos ainda que apesar de verificarmos semelhanças naqueles objetos produzidos para mostrar as comunidades externamente, notamos diferenças consideráveis entre a produção dos objetos utilitários incorporados ao cotidiano indígena.

Por fim, pensamos que cada grupo Potiguara de Catu e Sagi, unidos como pertencentes a uma mesma etnia, entretanto, dentro das suas particularidades, escolheu seu próprio repertório de conhecimentos, selecionando o que e como, se apresentar perante a sociedade não indígena, afirmando assim uma identidade que foi historicamente invisibilizada e quando não, marginalizada.

Pensamos que os processos de afirmação política dos povos indígenas do Brasil (OLIVEIRA, 1999) estão integrados aos seus modos de ser e estar no mundo. A "empeleitada" não cessa, continua diretamente relacionada à luta política em busca de afirmação étnica Potiguara e do fazer artesanal nas comunidades Catu dos Eleotérios e Sagi-Trabanda.

\section{REFERÊNCIAS}

ARRUTI, José Maurício; SIMONI, Alessandra. T.; BORGES, Virginia. Apresentação do dossiê Arte e Sociedade Indígena: diálogos sobre patrimônio e mercado. PROA: Revista de Antropologia e Arte, v. 5, p. 7-18, 2014.

CANCLINI, Nestor Garcia. Culturas híbridas: estratégias para Entrar e Sair da Modernidade. Tradução Heloísa Pezza Cintrão, Ana Regina Lessa. 4ª. Ed. - São Paulo: Editora da Universidade de São Paulo, 2003. (Ensaios Latino americanos, 1).

CASCUDO, Luís da Câmara. História da Alimentação no Brasil. 3ª ed. São Paulo: Global, 2004. 
CAVIGNAC, Julie Antoinette. A etnicidade encoberta: Índios e negros no Rio Grande do Norte. Mneme Revisa de Humanidades, Caicó, v. 4, n. 8, 2003, p.01-79.

CAVIGNAC, Julie Antoinette. Caboclas brabas e tapuias amansados: uma história mal contada. Perigo iminente, v. 2, , 2012 p. 57-63.

CHAVARRIA, Joaquim. La Cerámica. Traduçâo Rui Pires Cabral. Parramón Ediciones, A.A.,1992. Barcelona, Espanha.

Dicionário Houaiss de Língua Portuguesa. 1ª. Edição, Rio de Janeiro: Editora Objetiva, 2001.

GONÇALVES, José Reginaldo Santos. A retórica da perda: os discursos do patrimônio cultural no Brasil. Rio de Janeiro: Editora da UFRJ, MinC/IPHAN, 1996.

GRUNEWALD, Rodrigo de Azeredo. As múltiplas incertezas do Toré. In: GRUNEWALD, R. A.(org.). Tore: regime encantado dos índios do Nordeste. Ed. Massangana (FUNDAJ). Recife, 2004.

INGOLD, Tim. Trazendo as coisas de volta à vida: emaranhados criativos num mundo de materiais. Horizontes Antropológicos, Porto Alegre, ano 18, n. 37, p. 25-44, jan./jun. 2012.

LAGROU, E. Arte ou artefato? Agência e significado nas artes indígenas. IN: Proa Revista de Antropologia e Arte [on-line]. Ano 02, vol.01, n. 02, nov. 2010.

LIMA FILHO, Manuel Ferreira; SILVA, Telma Camargo da. A arte de saber fazer grafismo nas bonecas Karajá. Horizontes antropológicos. 2012, vol.18, n.38, pp.45-74. ISSN 0104-7183.

LIMA, Ricardo Gomes. Objetos: percursos e escritas culturais. São José dos Campos/SP: Centro de Estudos da Cultura Popular; Fundação Cassiano Ricardo, 2010.

0 Povo do Candeal. 1ª ed. Rio de Janeiro: Aeroplano, 2012.

LOPES, Fátima Martins. Em nome da liberdade: as vilas de índios do Rio Grande do Norte sob o Diretório Pombalino no século XVIII. Tese de Doutorado em História do Norte-Nordeste. Universidade Federal de Pernambuco, UFPE, Brasil, 2005.

MASCELANI, Ângela. 0 mundo da arte popular brasileira. Rio de Janeiro: Museu Casa do Pontal / Mauad Editora, 2002.

MERLEAU-PONTY, Maurice. Fenomenologia da Percepção. São Paulo: Martins Fontes, 2011.

OLIVEIRA, João Pacheco de. Entrando e saindo da "mistura": os índios nos censos nacionais. IN: OLIVEIRA, J. P. Ensaios em antropologia histórica. Rio de Janeiro: Editora UFRJ, 1999, 272 pp.

OLIVEIRA, João Pacheco de. Uma etnologia dos índios misturados'? Situação colonial, territorialização e fluxos culturais. In: OLIVEIRA, J. P.. A viagem de volta. Etnicidade, política e reelaboração cultural no Nordeste Indígena. Rio de Janeiro, Contra Capa, 1999a. 350pp. 
Uma etnologia dos "índios misturados"? Situação colonial, territorialização e fluxos culturais. Mana [online]. 1998, vol.4, n.1, pp.47-77. ISSN 0104-9313. http://dx.doi.org/10.1590/S010493131998000100003.

PEIRANO, Marisa. A favor da etnografia. Rio de Janeiro: Relume-Dumará. Textos escolhidos de arte e cultura populares - Vol. 1, no. 1 (nov. 2004). Rio de Janeiro: UERJ: Instituto de Artes, 1995.

PEREIRA, Maria Gorete Nunes. Potiguara de Sagi: da invisibilidade ao reconhecimento étnico. 2015. 207f. Dissertação (Mestrado em Antropologia Social) - Centro de Ciências Humanas, Letras e Artes, Universidade Federal do Rio Grande do Norte, Natal, 2015.

PRICE, Sally. Arte Primitiva em Centros Civilizados. Tradução: Inês Alfano. Revisão técnica: José Reginaldo Santos Gonçalves. Rio de Janeiro: Editora UFRJ, 2000.

SENAC. DN. 0 pão na mesa brasileira. $2^{\text {a }}$. Ed. /Arthur Bosisio Júnior (Org.); Raul Giovanni da Motta Lody, Rio de Janeiro; Ed. Senac Nacional, 2005.

SILVA, Cláudia Maria Moreira da. Em busca da realidade...: a experiência da etnicidade dos Eleotérios (Catu/RN). 2007. 281 f. Dissertação (Mestrado em Antropologia Social) - Universidade Federal do Rio Grande do Norte, Natal, 2007.

SIGAUD, Lygia. Os clandestinos e os Direitos. Estudos sobre os trabalhadores de cana de açúcar de Pernambuco. São Paulo: Livraria Duas Cidades, 1979.

SOLER, Juan; BARCELLOS, Lucival. Paraíba Potiguara. João Pessoa, Editora Universitária UFPB, 2012.

VALLE, Carlos Guilherme Octaviano do. Compreendendo a dança do torém: Visões de folclore, ritual e tradição entre os Tremembé do Ceará. Revista Anthropológicas, ano 9, volume 16(2): 187-228 (2005).

VIEIRA, José Glebson. Amigos e competidores: política faccional e feitiçaria nos Potiguara da Paraíba. São Paulo: Faculdade de Filosofia, Letras e Ciências Humanas, Universidade de São Paulo, 2010, 365p. Tese de doutorado em Ciências Sociais (antropologia social).

VIDAL, Lux. Grafismo indígena: estudos de antropologia estética. São Paulo: FABESP, 1992.

Recebido em 29 de dezembro de 2017. Aprovado em 03 de junho de 2018. 